\title{
The use of fourth extensor compartment artery bone flap in Kienböck's disease
}

\author{
Kienböck hastalığında dördüncü ekstansör kompartman arter kemik flebi kullanımı
}

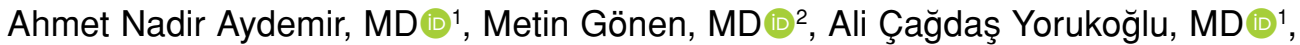 \\ Mehmet Yücens, MD (D) 1 , Ahmet Fahir Demirkan, MD (1) 1 \\ 1Department of Orthopedics and Traumatology, Pamukkale University, Faculty of Medicine, Denizli, Turkey \\ ${ }^{2}$ Department of Orthopedics and Traumatology, Develi Hatice Muammer Kocatürk State Hospital, Kayseri, Turkey
}

\section{ABSTRACT}

Objectives: This study aims to clinically evaluate the efficacy of pedicle bone flap treatment in stage II Kienböck's disease.

Patients and methods: This retrospective study included 10 patients ( 8 males, 2 females; mean age 33.3 years; range, 23 to 46 years) treated with pedicle bone flap between January 2012 and June 2016. In all patients, a fourth extensor compartment artery (ECA) pedicle bone flap from the dorsal surface of the radius was prepared and placed through a window opened on the lunate bone. Clinical results of the patients were evaluated according to the Mayo wrist score.

Results: All patients could return to their daily activities after surgery. No superficial or deep infection developed requiring debridement or antibiotic use other than prophylaxis. None of the patients required reoperation due to complications or the progression of the disease. The mean Mayo wrist score was measured as 81 (good).

Conclusion: In this study, results of the fourth ECA pedicle bone flap application were found to be effective in the treatment of avascular necrosis of the lunate bone. Further comparative and long-term follow-up studies are required including large and homogeneous patient groups.

Keywords: Kienböck, osteonecrosis, pedicle bone flap.

Avascular necrosis (AVN) of the lunate is a condition which leads to subchondral ischemic damage to the lunate bone and collagenous bone

\section{ÖZ}

Amaç: Bu çalışmada evre II Kienböck hastalığında pediküllü kemik flebi tedavisinin etkinliği klinik olarak değerlendirildi.

Hastalar ve yöntemler: Bu retrospektif çalışmaya Ocak 2012 - Haziran 2016 tarihleri arasında pediküllü kemik flebi ile tedavi edilen 10 hasta ( 8 erkek, 2 kadın; ort. yaş 33.3 yıl; dağılım, 23-46 yıl) dahil edildi. Tüm hastalarda, radiusun dorsal yüzeyinden dördüncü ekstansör kompartman arter (EKA)'in pediküllü kemik flebi hazırlandı ve lunat kemiği üzerinde açılan bir pencereden yerleştirildi. Hastaların klinik sonuçları Mayo el bilek skoruna göre değerlendirildi.

Bulgular: Tüm hastalar cerrahi sonrasında günlük aktivitelerine geri dönebildi Profilaksi dışında debridmanı veya antibiyotik kullanımını gerektiren yüzeyel veya derin enfeksiyon gelişmedi. Hastaların hiçbirinde komplikasyon veya hastalı̆̆ın progresyonu nedeniyle yeniden ameliyata gerek olmadı. Ortalama Mayo bilek skoru 81 (iyi) olarak ölçüldü.

Sonuç: $\mathrm{Bu}$ çalışmada, lunat kemiğin avasküler nekrozunun tedavisinde dördüncü EKA'nın pediküllü kemik flebi uygulamasının sonuçları etkili bulundu. Büyük ve homojen hasta gruplarını içeren ileri karşılaştırmalı ve uzun dönem takip çalışmaları gereklidir.

Anahtar sözcükler: Kienböck, osteonekroz, pediküllü kemik flebi.

resulting in degeneration of the wrist. Mechanical factors such as negative ulnar variance, vascular problems, and trauma contribute to the etiology

Received: January 08, 2019 Accepted: March 15, 2019 Published online: May 27, 2019

Correspondence: Ahmet Fahir Demirkan, MD. Pamukkale Üniversitesi Tıp Fakültesi Ortopedi ve Travmatoloji Anabilim Dalı, 20070 Kınıklı, Kayseri, Turkey. Tel: +90 536- 2607363 e-mail: fahirdemirkan@yahoo.com 
of AVN of the lunate bone, in addition to the general conclusion that interosseous blood flow is weak. It has been shown that disruption in the intraosseous regional circulation is more likely to result in osteonecrosis of weak bones such as the lunate, compared to other bones. ${ }^{[1,2]}$

As in the etiology of Kienböck's disease, there is no general consensus on treatment. There is a wide range of treatment options ranging from conservative treatment to proximal row carpectomy. ${ }^{[3]}$ With the identification of vascular insufficiency in the etiology, attempts have been made for revascularization in the treatment of the disease.

The fourth extensor compartment artery (ECA) is located on the radial aspect of the fourth extensor compartment floor. It originates from the dorsal branch of the anterior interosseous artery or its fifth extensor compartment branch and anastomoses with the dorsal intercarpal arch and the radiocarpal arch. The fourth ECA gives nutrient vessels to the floor of the fourth compartment that supplies cortical and cancellous bone of distal radius.

To the best of our knowledge, only one study has been reported in the literature regarding the use of pedicle bone flaps in stage III Kienböck's disease. ${ }^{[4]}$ Therefore, in this study, we aimed to clinically evaluate the efficacy of pedicle bone flap treatment in stage II Kienböck's disease..$^{[5]}$

\section{PATIENTS AND METHODS}

Patients admitted to the Pamukkale University Faculty of Medicine Orthopaedics and Traumatology Department Hand Unit between January 2012 and June 2016 were screened retrospectively for a diagnosis of AVN of the lunate. Of the 45 patients treated surgically, 10 patients ( 8 males, 2 females; mean age 33.3 years; range, 23 to 46 years) with fourth ECA bone flap were included in the study. Bone flap was applied to stage II patients according to Lichtman's classification. ${ }^{[6]}$ All patients' anteroposterior and lateral wrist radiographs and 1.5 Tesla magnetic resonance imaging (MRI) with a slice thickness of $2 \mathrm{~mm}$ were taken. Lunate bone still with the regular round shape seen to be preserved on radiographs and those with loss of signal intensity on $\mathrm{T}_{1}$ - and $\mathrm{T}_{2}$-weighted sequences were accepted as stage II (Figures 1 and 2). The study protocol was approved by the Pamukkale University Faculty of Medicine Ethics Committee. A written informed consent was obtained from each patient. The study was conducted in accordance with the principles of the Declaration of Helsinki.
After general anesthesia, the patient was positioned supine and a single course of $1 \mathrm{~g}$ cefazolin antibiotic prophylaxis was given. The procedure was carried out under loupe magnification. The tourniquet was not used, which allowed the small vessels to remain visible. A dorsal wrist approach with a transverse incision of $4 \mathrm{~cm}$ long was performed and the extensor retinaculum was opened longitudinally at the fourth compartment. The fourth ECA was found on the radial aspect of the fourth extensor compartment floor. Posterior interosseous nerve terminal branch denervation was added to this approach. After identifying the fourth compartment artery, the artery was divided near the interosseous membrane. One cubic milliliter of bone flap was harvested from the dorsal distal radius, centered $1-1.5 \mathrm{~cm}$ proximal to the joint, with the use of scalpel, cortex of the bone was cut with great caution from the proximal, radial and ulnar sides, a bone block of $1 \times 1 \times 1 \mathrm{~cm}$ was elevated with an elevator. The pedicle was elevated from the cortex of the bone with the help of elevator and sharp dissection (Figure 3). A capsulotomy was performed and a window was opened on the lunate bone with a small diameter drill followed by a large diameter drill and the necrotic bone inside was curetted until the subchondral bone. The window on the lunate was widened with the blade and the mobilized fourth ECA bone flap based on the retrograde blood flow from the dorsal intercarpal arch was transferred and inserted into the lunate.

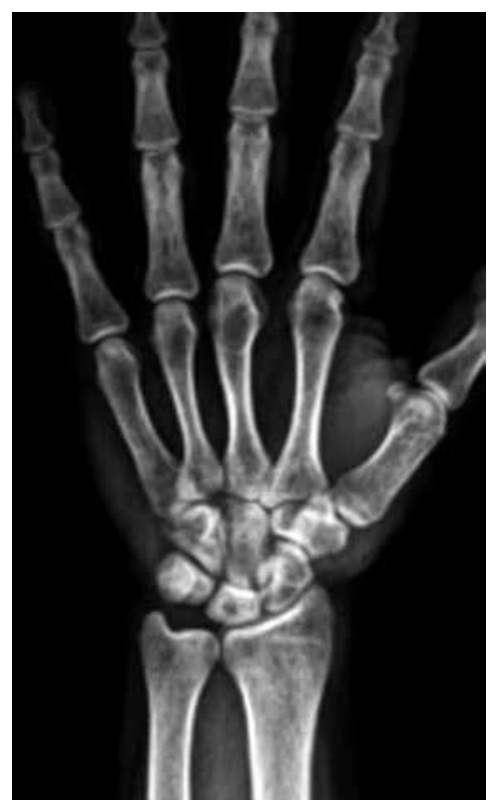

Figure 1. Preoperative radiograph images of patient 2. 

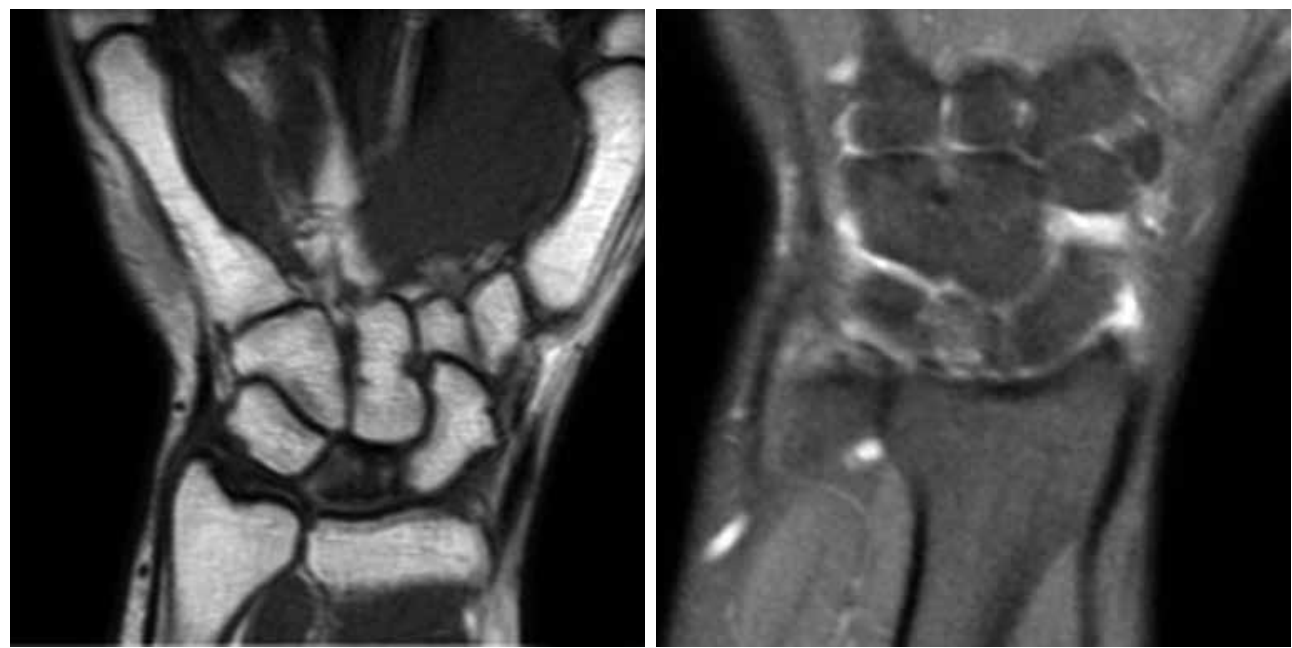

Figure 2. Preoperative coronal plane magnetic resonance images of patient 2. Notice abnormal lunate bone marrow signal.

Postoperatively, a short arm plaster splint was applied and range of motion exercises were started in the sixth week. The clinical results of the patients were evaluated with Mayo wrist scoring. Anteroposterior and lateral wrist radiographs were taken at postoperative follow-up examinations (Figure 4).

\section{Statistical analysis}

All statistical analyses were performed using the Statistical Package for the Social Sciences version 13.0 for Windows (SPSS Inc., Chicago, IL, USA).

\section{RESULTS}

The mean follow-up period was 33.5 months (range, 18-48 months). Surgery was applied to the left wrist of four patients and the right wrist of six. None of the patients had any significant trauma history. One patient had history of smoking. None of the patients had received any treatment for Kienböck's disease before the diagnosis. One patient was a housewife who was engaged in housework irregularly, three patients were working in a textile factory, one patient was working as a security personnel, two patients had office jobs and others (a)
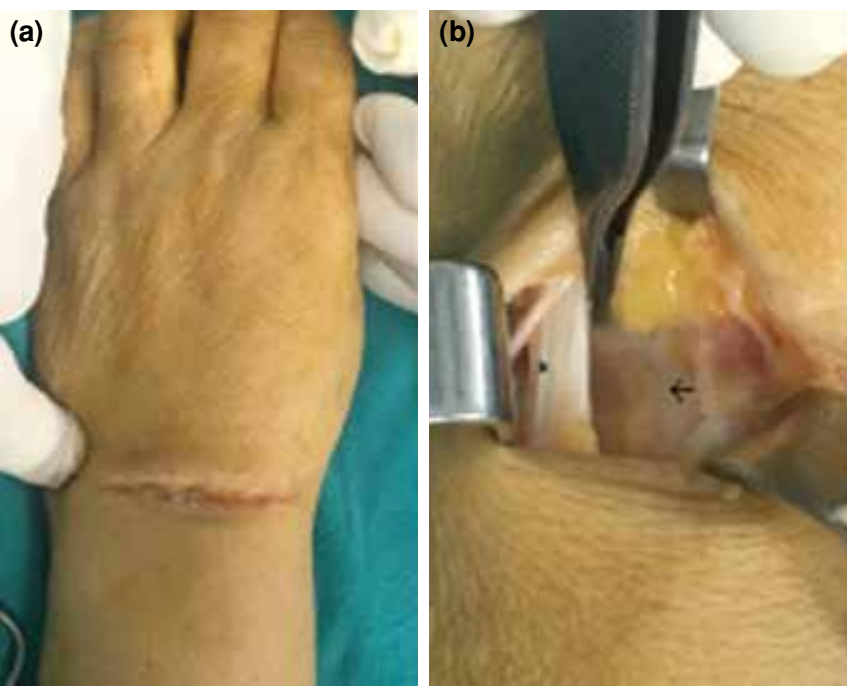

Figure 3. (a) Dorsal wrist approach with transverse incision. (b) extensor digitorum communis, identifying fourth compartment artery. * Extensor digitorum communis; $\leftarrow$ : Fourth extensor compartment artery.
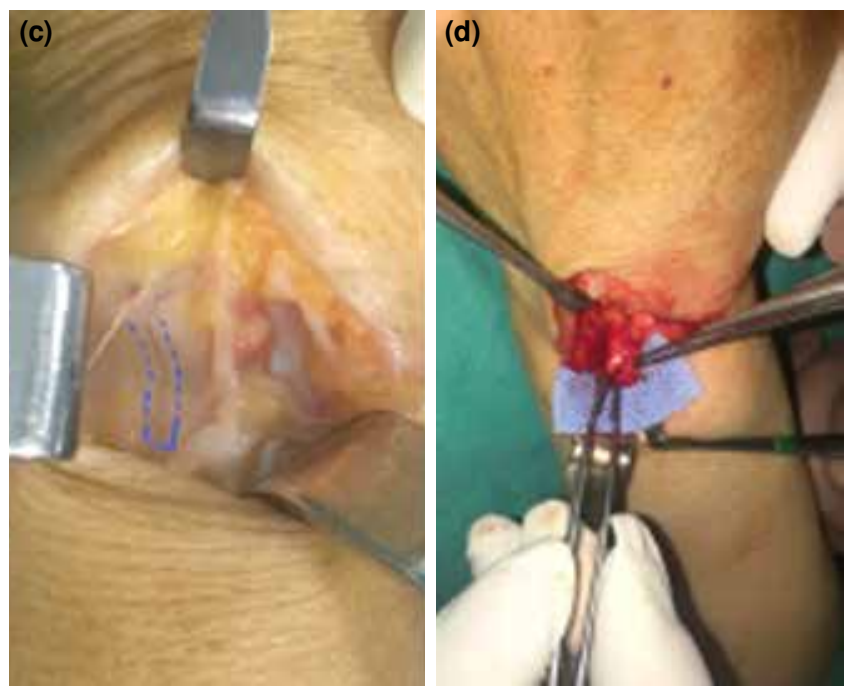

b) Extensor retinaculum opened. (c) After radial elevation of . (d) Bone flap harvested from dorsal distal radius. 


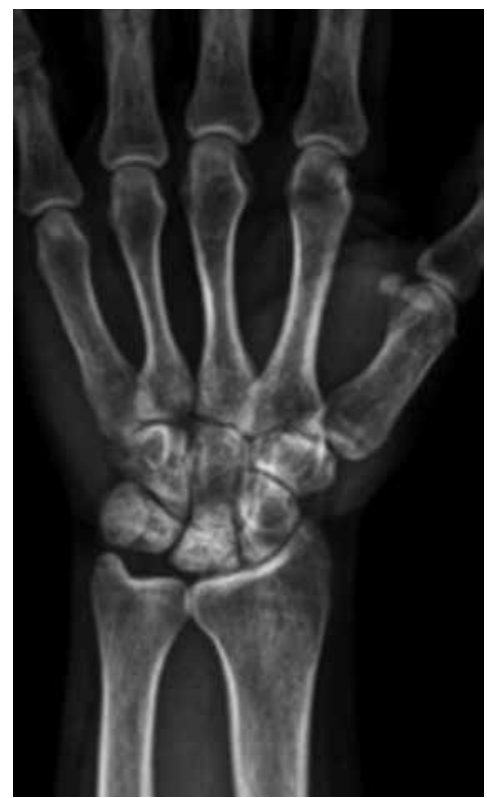

Figure 4. Postoperative fourth-year radiograph images of patient 2 .

were farmers. None of the patients changed their previous jobs postoperatively.

None of the patients had reoperations due to complications or progression of the disease. There was no superficial or deep infection requiring debridement or antibiotic use other than prophylaxis. All patients could return to their daily activities after surgery. Follow-up MRI was applied to all patients postoperatively at the end of first year that showed the return of normal lunate marrow signal (Figure 5). At the final follow-up, there was a return of normal signal intensity in both $T_{1}$ and $T_{2}$ MRI slices in all patients. None of the patients progressed to stage III or IV. There were small cysts in the lunate on $\mathrm{T}_{2}$ images in some patients; however, there were no symptoms in these patients. When the clinical results of the patients were evaluated according to the Mayo wrist score, the mean value was measured as 81 (good). The values were summarized in Table I. Seven patients had negative ulnar variance; however, Mayo wrist scores of these patients had no significant statistical difference.

\section{DISCUSSION}

The concept of revascularization of avascular bone tissues after vascular bundle transplantation was demonstrated by Hori et al. ${ }^{[7]}$ in studies on dogs. There are different options in the selection of vascularized bone flap (VBF) such as fourth or fifth metacarpal bone, dorsal or volar radial flaps or free bone flaps from other bones.

One of the largest patient series in the literature is the study by Arora et al. ${ }^{[8]}$ In 23 patients with $\mathrm{VBF}$, free vascularized iliac flaps were preferred, and progression was prevented in $87 \%$ of patients after an average of 13-year follow-up. Another long follow-up study of five patients reported that after the application of pedicle bone flaps obtained from the radial dorsal, no additional surgical intervention was required in any patient, although one patient found it necessary to change jobs during the follow-up period. ${ }^{[9]}$ In the current study, the average follow-up period was 33.5 months and all patients were able to resume daily activities and employment.
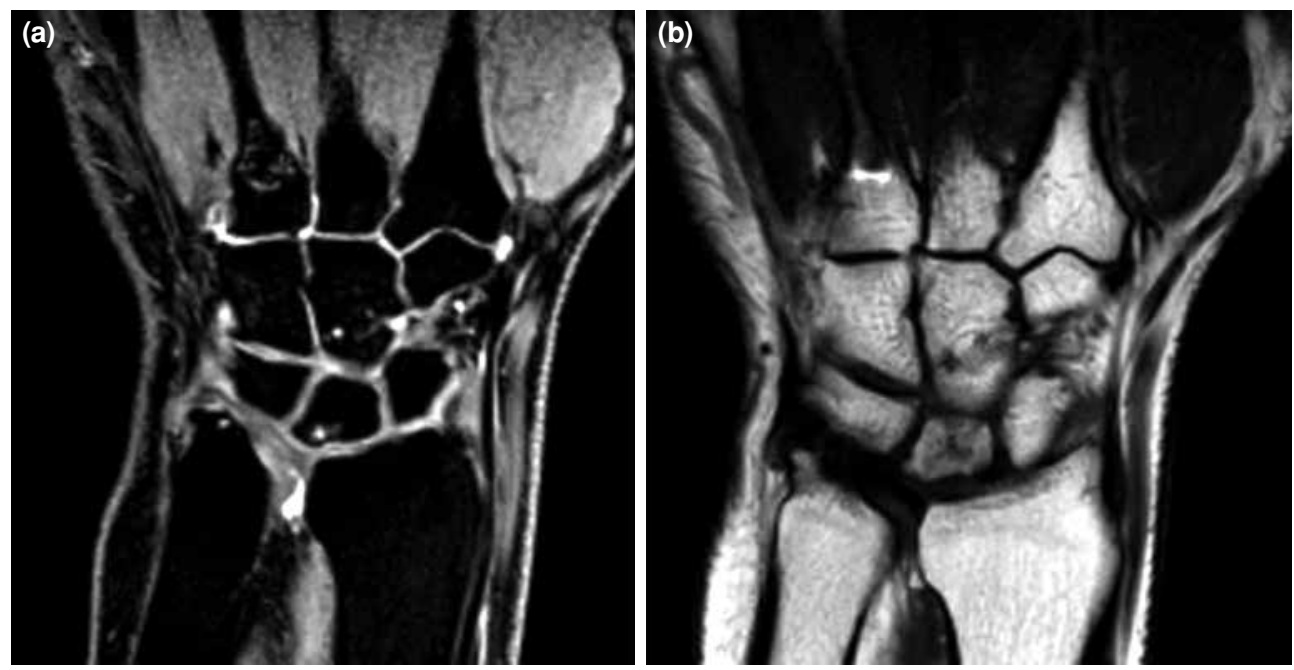

Figure 5. Postoperative coronal plane magnetic resonance images of patient 2. Notice return of normal lunate marrow signal. 
TABLE I

Mayo wrist scores of patients

\begin{tabular}{cccccc}
\hline & Pain intensity & Functional status & Range of motion & Grip strength & Total score \\
\hline Patient & & & & & \\
1 & 20 & 25 & 15 & 15 & 75 \\
2 & 25 & 25 & 15 & 25 & 90 \\
3 & 15 & 20 & 15 & 25 & 75 \\
4 & 20 & 20 & 15 & 15 & 70 \\
5 & 20 & 20 & 15 & 25 & 80 \\
6 & 15 & 20 & 15 & 25 & 75 \\
7 & 25 & 25 & 25 & 25 & 100 \\
8 & 20 & 20 & 15 & 25 & 80 \\
9 & 20 & 25 & 15 & 15 & 75 \\
10 & 25 & 25 & 15 & 25 & 90 \\
Mean & 20.5 & 22.5 & 16 & 22 & 81 \\
\hline
\end{tabular}

In our technique, the fourth ECA artery bone flap was prepared from the dorsal distal radius, using the pedicle bone graft technique described by Sheetz et al. ${ }^{[10]}$ Though the flap is described in that article, the use of fourth+fifth ECA bone flap is preferred in the literature. Moran et al. ${ }^{[1]]}$ used fourth ECA bone flap with a lengthened pedicle with fifth ECA in the treatment of Kienböck's disease. Of the total patient group, $77 \%$ showed no further collapse on follow-up radiographs, and $71 \%$ of patients showed evidence of revascularization with improvement in the $T_{2}$ and $T_{1}$ signals. Fifth ECA may establish distal connections to the fourth ECA; however, these anastomoses are not constant. Proximally, the fourth ECA was supplied directly by the posterior division of the anterior interosseous artery $(55 \%)$ or by the fifth ECA $(45 \%) .{ }^{[12]}$ The use of this flap sacrifices two arteries instead of one giving the vascular supply of both distal ulna and radius and contributing to dorsal carpal arch.

Sotereanos et al. ${ }^{[12]}$ described a distally based capsuloligamentous bone flap that was harvested from the dorsal distal radius that requires minimal pedicle dissection. This technique was used for proximal scaphoid pseudarthrosis. The vascular supply of this bone flap is based on the fourth ECA. Park et al. ${ }^{[4]}$ treated 13 patients with Kienböck's disease with the placement of fourth ECA VBF; however, only one of the cases was stage II while the others were stage III.

At preoperative MRI, areas of decreased signal intensity on $T_{1}$ slices and variable signal intensity on $\mathrm{T}_{2}$ slices were found. Follow-up postoperative MRI images demonstrated gradual graft incorporation and bone healing. Magnetic resonance imaging is an important tool to assess the recovery of the disease. Return of normal signal intensity was observed in all of our patients. Transverse incisions following Langer's lines at the dorsal wrist are superior to longitudinal incisions as they are believed to cause fewer adhesions to the extensor tendons. They are adjustable, can be extended as needed, while the whole area from metacarpal base to proximal ulna \& radius can be visualized. Unlike the other articles, ${ }^{[4]}$ the technique described in this article is transverse rather than longitudinal. Denervation of posterior interosseous nerve terminal branch may be added to this approach.

The bone flap can be applied alone or combined with other surgical techniques. In a study by Zafra et al., ${ }^{[13]}$ presented a series of five cases of lateral shortening of the radius and closing wedge osteotomy combined with second metacarpal bone flap based on the dorsal artery of the first metacarpal, and the results showed that this technique was effective. In a study by Fujiwara et al. ${ }^{[14]}$ of 18 patients with Lichtman stage IIIB disease, radial shortening was added performed by three different hand surgeons. In the VBF application, the pedicle bone graft was taken from the radius or metacarpal according to the surgeon's preference. The results were evaluated using the Mayo score, and long-term results were found to be positive.

In the current study, all patients were operated on by a single surgeon and no separate osteotomy or fixation technique was applied in combination with the bone flap. In the assessment of the current study results with the Mayo scoring, the mean value was 
measured as 81 (good). Although seven patients in the study had negative ulnar variance, Mayo wrist scores of these patients had no significant statistical difference. The impaction of the flap through the window on the lunate was sufficient, although in some cases, the size of flap had to be reduced to fit the window.

There were some limitations in this study. First, the study was performed retrospectively and preoperative Mayo scores were not provided for all patients. Moreover, long-term follow-up results were not included, and although the number of patients was limited to 10, the overall incidence of Kienböck's disease was low. There are few studies of large patient series in the literature. ${ }^{[15-17]}$ In this study, the results of patients who underwent bone flap surgery were evaluated and there was no control group for comparison of the effectiveness of the treatment.

In conclusion, we may conclude that fourth ECA bone flap is effective in the treatment of AVN of the lunate bone. The advantage of this technique is the use of transverse incision, the proximity of the pedicle and ease of harvest with less dissection, and that the flap can be pivoted into the lunate with minimal rotation. Nevertheless, there is a need for further comparative, long-term follow-up studies of large homogeneous patient groups.

\section{Declaration of conflicting interests}

The authors declared no conflicts of interest with respect to the authorship and/or publication of this article.

\section{Funding}

The authors received no financial support for the research and/or authorship of this article.

\section{REFERENCES}

1. Gelberman RH, Bauman TD, Menon J, Akeson WH. The vascularity of the lunate bone and Kienböck's disease. J Hand Surg Am 1980;5:272-8.

2. Freedman DM, Botte MJ, Gelberman RH. Vascularity of the carpus. Clin Orthop Relat Res 2001;383:47-59.

3. Cross D, Matullo KS. Kienböck disease. Orthop Clin North Am 2014;45:141-52.
4. Park IJ, Kim HM, Lee JY, Roh YT, Kim DY, Jeon NH, et al. Treatment of Kienböck's disease using a fourth extensor compartmental artery as a vascularized pedicle bone graft. J Plast Reconstr Aesthet Surg 2016;69:1403-10.

5. Atik OŞ. Which articles do we prefer to publish? Eklem Hastalik Cerrahisi 2018;29:1.

6. Lichtman DM, Lesley NE, Simmons SP. The classification and treatment of Kienbock's disease: the state of the art and a look at the future. J Hand Surg Eur Vol 2010;35:549-54.

7. Hori Y, Tamai S, Okuda H, Sakamoto H, Takita T, Masuhara K. Blood vessel transplantation to bone. J Hand Surg Am 1979;4:23-33.

8. Arora R, Lutz M, Zimmermann R, Struve P, Pechlaner S, Gabl M. Free vascularised iliac bone graft for Kienböck's disease stage III. Handchir Mikrochir Plast Chir 2010;42:198203. [Abstract]

9. Kirkeby L, von Varfalva Palffy L, Hansen TB. Longterm results after vascularised bone graft as treatment of Kienböck disease. J Plast Surg Hand Surg 2014;48:21-3.

10. Sheetz KK, Bishop AT, Berger RA. The arterial blood supply of the distal radius and ulna and its potential use in vascularized pedicled bone grafts. J Hand Surg Am 1995;20:902-14.

11. Moran SL, Cooney WP, Berger RA, Bishop AT, Shin AY. The use of the $4+5$ extensor compartmental vascularized bone graft for the treatment of Kienböck's disease. J Hand Surg Am 2005;30:50-8.

12. Sotereanos DG, Darlis NA, Dailiana ZH, Sarris IK, Malizos KN. A capsular-based vascularized distal radius graft for proximal pole scaphoid pseudarthrosis. J Hand Surg Am 2006;31:580-7.

13. Zafra M, Carrasco-Becerra C, Carpintero P. Vascularised bone graft and osteotomy of the radius in Kienböck's disease. Acta Orthop Belg 2005;71:163-8.

14. Fujiwara H, Oda R, Morisaki S, Ikoma K, Kubo T. Long-term results of vascularized bone graft for stage III Kienböck disease. J Hand Surg Am 2013;38:904-8.

15. Nakagawa M, Omokawa S, Kira T, Kawamura K, Tanaka Y. Vascularized bone grafts from the dorsal wrist for the treatment of kienböck disease. J Wrist Surg 2016;5:98-104.

16. Laravine J, Loubersac $T$, Gaisne $E$, Bellemère P. Evaluation of a shape memory staple $\left(\mathrm{Qual}^{\circledR}\right)$ in radial shortening osteotomy in Kienböck's disease: A retrospective study of 30 cases. Hand Surg Rehabil 2019;38:141-149.

17. Ho Shin Y, Yoon JO, Ryu JJ, Lee TK, Choi SW, Kwang Kim J. Pronator quadratus pedicled bone graft in the treatment of Kienböck disease: follow-up 2 to 12 years. J Hand Surg Eur Vol 2019 Mar 24:1753193419836628. [Epub ahead of print] 